\title{
IN MEMORIAM ANDRZEJ BARTNICKI (25 VI 1933 - 16 III 2004)
}

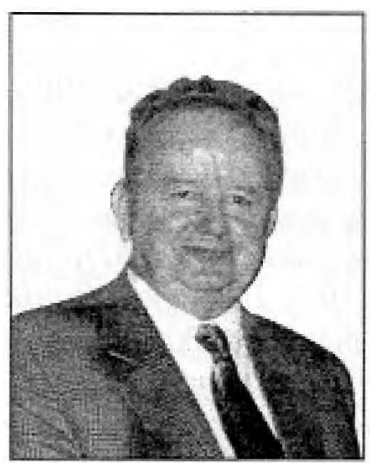

Podstępna choroba przedwcześnie przerwała życie wielkiego Uczonego, wspaniałego Mistrza i niezwykłego Człowieka.16 marca 2004 r. odszedł od nas na zawsze Profesor dr hab. Andrzej Bartnicki, wybitny historyk, który swe aktywne i niezwykle twórcze życie związał z Uniwersytetem Warszawskim, a potem z Wyższą Szkołą Humanistyczną w Pułtusku. 24 marca 2004 r. pożegnaliśmy Go na Powązkach, gdzie spoczął w Alei Profesorskiej.

Profesor Andrzej Bartnicki urodził się 25 czerwca 1933 r. w Raczynie. Od bardzo wczesnego dzieciństwa mieszkał w Zawidzu, z którym pozostał na zawsze bardzo emocjonalnie związany i zachował we wdzięcznej pamięci. Z domu rodzinnego wyniósł umiłowanie ojczystej ziemi, postawę obywatelską i zaintelesowania humanistyczne, a zwłaszcza historyczne. Historia stała się Jego wielką życiową pasją i profesją. Po skończeniu szkoły średniej Profesor podjął studia na Wydziale Historycznym Uniwersytetu Warszawskiego, które ukończył w 1957 r. Niedługo potem rozpoczął tu pracę dydaktyczną, równolegle podejmując badania nad doktoratem. Na Wydziale Historycznym Uniwersytetu Warszawskiego uzyskał stopień doktora (1966 r.) i doktora habilitowanego (1973 r.), a następnie również tytuł profesora (1977 r.).

Z Instytutem Historycznym Uniwersytetu Warszawskiego związany był Profesor przez wiele lat, łącząc aktywność naukową i dydaktyczną z pracą organizacyjną. W latach 1975-1976 był wicedyrektorem Instytutu Historycznego, a także inicjatorem i twórcą Ośrodka Studiów Amerykańskich i pierwszym jego dyrektorem. W latach 1978-1981 kierował Ośrodkiem, a potem w latach 1990-1994 przewodniczył jego Radzie Naukowej. Od 1982 r. był On kierownikiem Katedry Historii Najnowszej Powszechnej i Dziejów Stanów Zjednoczonych w Instytucie Historycznym. W latach 1986-1988 Prof. Bartnicki był wicedyrektorem Polish Studies Center w Bloomington w Indiana Uniwersity, przyczyniając się do rozwoju wymiany stypendialnej pomiędzy Uniwersytetem Warszawskim a uniwersytetami amerykańskimi. 
W latach 1984-1987 Profesor był członkiem Centralnej Komisji Kwalifikacyjnej ds. Kadr Naukowych. Pełnił też odpowiedzialne funkcje partyjne w Uniwersytecie, a od 1979 r. był zastępcą Kierownika Wydziału Nauki i Oświaty KC PZPR. Ale nigdy nie stracił zaufania kolegów, którzy otaczali Go zawsze życzliwością i szacunkiem.

Zainteresowania badawcze Profesora Andrzeja Bartnickiego od początku dotyczyły w głównej mierze historii powszechnej XIX i XX w. , a w szczególności historii dyplomacji oraz polityki zagranicznej Wielkiej Brytanii i Stanów Zjednoczonych. Profesor był laureatem wieiu prestiżowych stypendiów. Prowadził badania naukowe w licznych placówkach zagranicznych, m.in. w Austrii, Czechosłowacji, Wielkiej Brytanii, Republice Federalnej Niemiec i wielokrotnie w Stanach Zjednoczonych. Utrzymywał kontakty naukowe $\mathrm{z}$ wybitnymi badaczami nie tylko w kraju i Europie, ale w szczególności w Stanach Zjednoczonych. Był chętnie zapraszany za granicę na wykłady i konferencje naukowe. Stopniowo poszerzał pole badawcze, zarówno pod względem chronologicznym, jak i tematycznym, o czym dobitnie świadczą kolejne Jego publikacje.

Plon prac badawczych Profesora Andrzeja Bartnickiego jest niezwykle obfity ponad 20 książek oraz ponad 150 artykułów i recenzji opublikowanych w pismach krajowych i zagranicznych. Odnotujmy najważniejsze prace książkowe, które na trwałe weszły do dorobku światowej historiografii (choć ta lista jest znacznie bogatsza). Były to: Pierwszy front II wojny światowej (konflikt wtosko-etiopski, 1935-1937), Warszawa 1971; Konflikty kolonialne, 1869-1939, Warszawa 1971; Historia Etiopii, Wrocław 1971 (warto dodać, że miała zagraniczne wydania, m.in. rosyjskie i niemieckie); Egipt i Sudan w polityce Wielkiej Brytanii, 1882-1936, Warszawa 1974; Encyklopedia historii Stanów Zjednoczonych Ameryki. Dzieje polityczne (od Deklaracji Niepodlegtości do wspótczesności), Warszawa 1992; Walka o Morze Czerwone 1527-1868, Warszawa 1993; Historia Stanów Zjednoczonych Ameryki, 1607-1990, t. I-V, Warszawa 1995; Historia Afryki, Wrocław 1996; Zarys aziejów Afryki i Azji 1869-1996. Historia konfliktów, Warszawa 1996; Leksykon świata, Warszawa 1998.

Profesor Andrzej Bartnicki brał też udział w licznych konferencjach naukowych i koordynował wiele zespołowych przedsięwzięć, szeroko promując badania nad historią powszechną, a zwłaszcza badania amerykanistyczne. Warto szczególnie podkreślić, że z Jego inicjatywy i z Jego udziałem powstały pionierskie, niezwykle ważne i wręcz unikalne prace dotyczące dziejów USA: Encyklopedia historii Stanów Zjednoczonych Ameryki. Dzieje polityczne (od Deklaracji Niepodlegtości do wspótczesności), Warszawa 1992 oraz pięciotomowa Historia Stanów Zjednoczonych Ameryki, 1607-1996, Warszawa 1995.

Profesor Andrzej Bartnicki był założycielem w 1976 r. specjalistycznego periodyku „American Studies”, który przez lata był najlepszą wizytówką badań amerykanistycznych w Polsce. Przez wiele lat współpracował On także z magazynem historycznym „Mówią Wieki” oraz „Przeglądem Humanistycznym”, w którym od 1977 roku pełnił obowiązki zastępcy redaktora. Przez wiele lat Profesor należał również do grona redakcyjnego „Dziejów Najnowszych”.

Profesor Andrzej Bartnicki był twórcą Wyższej Szkoły Humanistycznej w Pułtusku, którą kierował jako Rektor od 1994 r. przez kolejnych 10 lat, do swojej przed- 
wczesnej śmierci. Szkoła ta była niewątpliwie Jego wielkim dziełem wizjonerskim i w gruncie rzeczy autorskim. Swoje śmiałe plany (dla wielu „nierealne mrzonki”) Profesor konsekwentnie i z powodzeniem realizował, rozbudowując Wyższą Szkołę Humanistyczną. Stała się ona jedną z najlepszych szkół niepublicznych w Polsce (o czym świadczyły także rankingi) i nieprzypadkowo nazywano ją Oxfordem nad Narwią. W przyszłości miała, zgodnie z marzeniami i planami Rektora, stać się Uniwersytetem Mazowieckim, służącym potrzebom mieszkańców tego regionu. Niestety, zabrakło Mu czasu, by ten wizjonerski, a przy Jego oddaniu i zaangażowaniu z pewnością realistyczny, plan zrealizować.

Profesor Andrzej Bartnicki był również znakomitym dydaktykiem, a Jego zajęcia zawsze cieszyły się dużym zainteresowaniem i uznaniem studentów. Na Jego seminaria magisterskie i doktorskie uczęszczali studenci i doktoranci nie tylko z kraju, ale i z zagranicy, m.in. z Bliskiego Wschodu. Dzisiaj niektórzy z nich sprawują ważne funkcje w swoich krajach, są profesorami Uniwersytetu Warszawskiego, pełnią wysokie funkcje w dyplomacji etc. Pod opieką naukową Profesora powstało łącznie ponad 140 prac dyplomowych, a wielu Jego uczniów kontynuuje zainteresowania badawcze historią powszechną.

Profesora Andrzeja Bartnickiego poznałam w 1977 roku, kiedy zaczęłam uczęszczać na prowadzone przez Niego seminarium doktorskie poświęcone historii powszechnej. Wybrałam seminarium Profesora, gdyż znałam Jego prace i wiedziałam, że jest On znakomitym historykiem. Niedługo potem mogłam się przekonać, że jest On również wspaniałym Nauczycielem i cudownym Człowiekiem. Cotygodniowe wtorkowe spotkania seminaryjne w Instytucie Historycznym wspominam z wielką serdecznością i wdzięcznością. Moi koledzy seminaryjni zajmowali się rozmaitymi zagadnieniami, poczynając od historii Bliskiego Wschodu, Maroka, Hiszpanii, po dzieje Jugosławii, Europy Środkowej i oczywiście Stanów Zjednoczonych. Profesor uważnie i niezwykle życzliwie przysłuchiwał się naszym nieraz burzliwym dyskusjom, umiejętnie nimi kierując. Nierzadko zmieniał całkowicie ich kierunek, inspirując nas do dalszych przemyśleń i poszukiwań badawczych. Ale też czasem przyznawał nam rację i dawał się przekonać do naszych pomysłów. Po kilku spotkaniach seminaryjnych, kiedy już rozpoznałam bazę źródłową i dysponowałam pewną wiedzą, udało mi się Go bez trudu pozyskać dla tematu doktoratu, który miał być poświęcony Herbertowi Hooverowi, a nie któremuś z wielkich prezydentów, jak Woodrow Wilson czy Franklin Delano Rosoevelt.

Profesor miał dla nas zawsze czas i tylko z sobie znaną cierpliwością wysłuchiwał naszych argumentów, racji, a także wątpliwości. Był zawsze uśmiechnięty, optymistyczny i wyrozumiały, choć także wymagający i ojcowsko krytyczny. Potrafił w nas wyzwalać niespożytą energię i chęć działania, także w realizacji wspólnych przedsięwzięć zespołowych. W niezwykle gościnnym domu państwa Kaliny i Andrzeja Bartnickich na Grotach spotykaliśmy się zawsze bardzo chętnie i były to dla nas, Jego uczniów, ważne wydarzenia, które wywierały znaczący wpływ na nasze zawodowe losy. Tam też rodziły się najlepsze pomysły i plany wspólnych przedsięwzięć, jak Encyklopedia historii Stanów Zjednoczonych czy pięciotomowa Historia Stanów Zjednoczonych. 
Profesor Bartnicki był człowiekiem o szerokich horyzontach, niespożytej energii, niezwykle pracowitym. Był otwarty, tolerancyjny, ciekaw świata i innych kultur. Posiadał niezwykłą umiejętność łączenia ludzi o różnych poglądach i przekonaniach. Żywo interesował się przeszłością i teraźniejszością kraju ojczystego, ale z podobną pasją i zaangażowaniem mówił o przyszłości, roztaczając przed nami coraz to nowe pomysły i rozliczne wizje rozwoju placówki, która kierował. Nie marnował czasu, a praca była dla Niego, jeśli nie Norwidowskim pięknem, to autentyczną przyjemnością i powołaniem. Profesor Bartnicki był człowiekiem czynu, inicjatorem wielu pomysłów, które z sukcesem realizował pozyskując zawsze grono chętnych i oddanych współpracowników. Lubił podróże i wciąż snuł plany dalszych wyjazdów w gronie najbliższych. Kochał zwierzęta, zwłaszcza psy, które przygarniał - z ulicy lub przytułku - i otaczał niezwykle troskliwą opieką. Z każdym rokiem powiększało się grono jego podopiecznych, zarówno na Grotach, jak i w Pułtusku.

Prof esor brał zawsze aktywny udział w życiu publicznym i uczestniczył w wielu pracach o charakterze społecznym. Był On m.in. współzałożycielem Mazowieckiego Towarzystwa Naukowego i Członkiem Honorowym Polskiego Towarzystwa Historycznego. W latach 1987-1989 był członkiem Komitetu Nauk Historycznych Polskiej Akademii Nauk. Był również współtwórcą Fundacji Rektorów Pol skich oraz przewodniczącym Rady Fundacji Instytut Społecznej Wiedzy. W latach 1997-1999 Profesor Bartnicki był członkiem Rady ds. Edukacji Europejskiej przy Ministrze Edukacji Narodowej.

Wszechstronna działalność Profesora Bartnickiego była wysoko ceniona nie tylko w środowisku, ale i najwyższych władz. Był honorowym obywatelem Pułtuska, Fromborka i Zawidza. W 2003 r. został finalistą Konkursu Przedsiębiorca Roku 2003. Profesor był laureatem wielu nagród, m.in. Nagrody Indywidualnej MEN (1997r.) i Nagrody Edukacyjnej „Perspektyw” w 2000 r. za stworzenie nowoczesnej uczelni. Prof. Bartnicki otrzymał wysokie odznaczenia państwowe, m.in. Złoty Krzyż Zasługi (1977 r.), Medal Komisji Edukacji Narodowej (1977 r.), Krzyż Kawalerski Orderu Odrodzenia Polski (1978 r.), Krzyż Oficerski Orderu Odrodzenia Polski (1984 r.), Odznakę Honorową za Zasługi dla Oświaty nadaną przez ministra Edukacji Narodowej (2001 r.), Krzyż Komandorski z Gwiazdą Orderu Odrodzenia Polski (2003 r.).

Dorobek naukowy Profesora Andrzeja Bartnickiego, z którego korzystają i będą korzystać kolejne pokolenia studentów i badaczy, zapewnił mu należne miejsce wśród luminarzy historii. Profesor dla nas, Jego uczniów i przyjaciót, jest i na zawsze pozostanie kimś bardzo bliskim i szczególnym oraz niedościgłym wzorem do naśladowania.

Bardzo trudno pisać o Zmarłym Mistrzu, którego zawsze podziwiałam i darzyłam wielkim szacunkiem, bo żadne słowa tego nie wyraża, jak wielką stratą jest Jego zbyt szybkie odejście. Był w pełni sił twórczych. Tyle mógł jeszcze dobrego zrobić...

W pamięci współpracowników i uczniów Profesor Andrzej Bartnicki pozostaje wspaniałym Nauczycielem, ukochanym Mistrzem i Człowiekiem wielkiej życzliwości. Od dnia Jego śmierci towarzyszy nam poczucie osamotnienia, bowiem z Jego odejściem każdy z nas stracił bezpowrotnie cząstkę samego siebie. 